\title{
Creative Entrepreneurial Applications In The Wood Industries: An Appalachian Case Study
}

Peter H. Hackbert, Berea College, USA

Tim Glotzback, Berea College, USA

Gary Mahoney, Berea College, USA

\begin{abstract}
This paper illustrates three academic units collaborative process to solve a design problem in the development of new wood products for the Historic Boone Tavern Hotel, Berea, Kentucky. The Boone Tavern Hotel chronology and renovation needs after 99 years are summarized. The Berea College Student Crafts Program is then described and the need for a new business model for designing innovative products is illustrated. The learning objectives within the academic program of the Technology and Industrial Arts Department's TEC 140 Class which became the "academic test case" for the collaborative experiment are described. Finally an innovative model for reviewing and executing rapid prototyping within the wood products class for possible adoption by the Boone Tavern Hotel and manufactured by the Student Craft Program is revealed.
\end{abstract}

\section{INTRODUCTION}

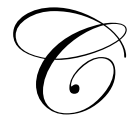

reative is an ambiguous concept generally applied to imaginative, inventive, artistic people and objects. The concept of the "creative economy" was first introduced in 2000 in Business Week (Coy, August 20, 2000). ${ }^{\text {i }}$ The UK Government Department for Culture, Media and Sport (DCMS) has produced a widelyquoted definition of the Creative Industries as:

"those industries which have their origin in individual creativity, skill and talent and which have a potential for wealth and job creation through the generation and exploitation of intellectual property." (DCMS 2001, p. 04)

"Appalachia is on the wrong end of the curve" in economics and education, says Martin Ramsay, chief institutional technologist at the Appalachian College Association, a non-profit consortium of 35 two- and four-year private and public colleges and universities in the five-state mountain region that includes Kentucky, North Carolina, Tennessee, Virginia, and West Virginia. About 39,000 students attend those schools, which have a combined faculty of about 3,250 (Kolbasku McGee, 2006, 1).

The poverty rate in Appalachia is $27 \%$, more than double the national average of $13 \%$. The high-school graduation rate in Appalachia lags 10\% behind the U.S. average, and college graduations in the region lag 35\% behind the national average, according to the Appalachian Regional Commission. Appalachian communities that invest in the arts reap the additional benefit of jobs, economic growth, and a quality of life that positions those communities to compete in our 21 st century creative economy (Lynch, 2007).

Regional prosperity depends on the productivity of all its industries and assets. Local services and infrastructure can have considerable impact on the performance of exporting industries. Florida (2008) states that there are no low-tech industries, only low tech firms - innovation can drive productivity in any industry so a sole focus on high-tech companies misses major opportunities to increase regional competitiveness. Florida (2002) believes that the ascendancy of certain professions and occupations associated with the new economy has given rise to a Creative Class that now drives the economy. While some might expect the core class includes the fields of 
computer and math, architecture and engineering, the social sciences, education, arts, design, entertainment, sports, the media and crafts

Richard Florida (2008, 107-109) provides indicators of the creative economy growth over the last century. Constituting just 5\% of all employment in 1900, the creative class rose to roughly 10 percent in 1950,15 percent in 1980 and more than 30 percent by 2005 . Today, nearly 40 million Americans hold jobs in the creative sector. At $\$ 2.1$ trillion the creative class members generates half of all wages and salaries and enjoy nearly 70 percent ( $\$ 474$ billion) of all discretionary incomes (Florida 2008, 107). These figures dwarf those of the service sector, which accounts for only 31 percent of all wages and salaries and only 17 percent of discretionary income. By 2014, according to Florida and researcher Kevin Stolarick the U.S. will add another 10 million creative sector jobs to the nation's economy. A similar pattern is forecasted for all of the advanced nations where the creative class makes up35 to 45 percent of the workforce, depending on the country. ${ }^{\text {ii }}$

The core creative industries within an economy are defined by Howkins, $(2001,116)$ as those that focus on creating and exploiting intellectual property products; research and development, publishing, software, TV and radio, design, music, toys and games, advertising, architecture, performing arts, crafts, video games, fashion, and art or providing business-to-business creative services such as advertising, public relations and direct marketing. Aesthetic live performance experiences are also included, contributing to an overlap with definitions of art and

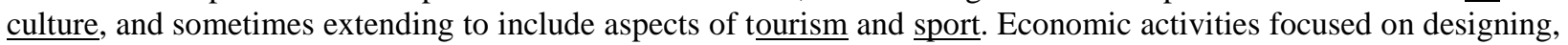
making and selling objects or works of art such as jewelry, haute couture, books of poetry or other creative writing, or fine art and crafts are also often feature in definitions of the creative sector because the value of such objects derives from a high degree of aesthetic originality. ${ }^{\text {iii }}$

An economy operates as a system and includes all of the other enterprises necessary to do business: those that sell, supply, reproduce, or otherwise contribute to the same products (Regional Technology Strategies, Inc. April 2007). Creative enterprises or businesses, like other industries, tend to cluster more heavily in some places than others, either because of a special location advantage, historical roots, or just a pure chance event. Creativity flourishes where creative people socialize, develop relationships, and form networks. An environment where ideas can be easily exchanged inspires creativity and serves as an engine of economic growth (Florida, 2008).

There are cultures within rural America that nurture, tolerate, or discourage the creation of new enterprises (Hustedde, 2007). The State of Arkansas classifies its creative economy as inputs, creation, production, dissemination, and support classifications. Taken collectively, these parts represent the full scope of the Arkansas creative economy. Inputs: Companies that provide materials, parts, or equipment used by the companies in the creation category e.g., art supply stores. Creation: All firms that produce original creative intellectual property, or whose competitive advantage relies on incorporating distinctive aesthetic material into their products or services. This includes self-employed people who originate creative concepts and merchandise. Production: Firms that reproduce art- or design-based goods or services such as film and video production, sound studios, publishers, printers, and art foundries. This component also includes manufacturing firms that incorporate art and design into their products but are not generally considered to be creative enterprises. Dissemination: Entities that deliver art- or design-based products to the public, such as book and music stores, theaters, and museums. Support System: Institutions that facilitate arts- and design-based activity, including schools, arts councils, nonprofits, arts incubators, agents, business services, and government agencies (Regional Technology Strategies, 2007). Arkansas reports 34,888 employed and self-employed state residents in the creative economy (Regional Technology Strategies, 2007). The City of Savannah, Georgia reports 1,606 full time equivalent jobs and generates $\$ 4.8$ million in local and state government revenue within a $\$ 46.63$ million industry (Lynch 2007) ${ }^{\mathrm{iv}}$.

The technologies associated with handicrafts are often developed by an individual and shared informally. The technologies used by architects and designers are most often the products of the information. For example, in rural Yancey and Mitchell County in the Appalachian region of North Carolina, local developers found an innovative way to use the methane gas given off by decaying trash to power the technologies of a range of creative enterprises. The Blue Ridge Resource Conservation and Development Council, HandMade in America, and Maryland Community College through a joint effort, converted a six-acre plot into an incubator space for glassblowers, ceramic artists, and horticulturalists (Regional Technology Strategies, Inc. 2003). A row of Quonset 
huts and greenhouses house the studios of the resident artisans, who each pay between $\$ 200$ and $\$ 350$ per month rent for up to three years. The facility also has a public art gallery and visitor center. The methane gases captured that would be released into the atmosphere are the equivalent of removing over 21,000 cars from state roads and is forecasted to provide sufficient power for up to 20 years. The proximity to the internationally renowned Penland School of Crafts helps attract tourists year round. The community college teaches the artisans business management and marketing skills. Funding has been provided by the Appalachian Regional Commission (Regional Technology Strategies, Inc. 2003).

\section{CREATIVE CONNECTIONS AND SPILL OVER}

Benefits of the creative economy spill over into many industries. The most obvious is in the tourism and hospitality sectors. Some parts of the creative economy are designed to attract visitors, and their success as measured in attendance and local spending patterns. Studies indicate that high concentrations of artists and performers are associated with high rates of tourism (Lynch 2007). The amenities that attract tourists also attract the creative personnel employed by technology - intensive companies (Florida, 2002; Wu, 2005). Creative economy clusters often coexist with lifestyle clusters, such as wellness and holistic health groups, and spiritual and retirement communities. Some elements of the arts and culture sectors correspond to lifestyle choices attractive to other special interest groups that hold similar values, such as organic farmers, environmentalists, and high tech entrepreneurs. In addition, spiritualism and wellness are associated with both creative art forms and specialty products. Many of the fastest-growing elements of the agriculture sectors rely on creativity - as creative labeling and marketing of organic and specialty foods, sustainable farming communities, wine, and beer; as farm families relying on craft products or foods or farm stays as secondary sources of income; and as home landscaping and garden design (Handmade 2003a, 2003b). Creative economies are linked to high technology and science based industries, both through the creative content of some technology - based industries like software design, computer and video games, bioinformatics and special effects and as a creative outlet for other high-tech employees.

\section{BOONE TAVERN HOTEL HISTORY AND CURRENT CHALLENGE}

In 1855 John G. Fee founded the settlement and school that would become Berea College. Fee, the son of a slaveholder, converts to abolitionism when he takes to heart two scriptures: "You shall love the Lord your God with all your heart ... and your neighbor as yourself," and "Do unto other what you would have them do unto you." Fee and his wife, Matilda, establish the basis for a school devoted to Christian values and acceptance of all people regardless of race, color, or gender (Wilson, 2006: 9-10). Edward Henry Fairchild replaces Fee in 1869 to serve as the President of Berea College giving "institutional form to Fee's dream of an interracial, coeducational school" (Wilson, 2006: 33). Fairchild serves until 1889. William B. Stewart begins a brief, two-year service as President of the college in 1890. During his tenure, the Berea College Industrial Department is established to teach the "useful arts" such as carpentry, blacksmithing, typesetting, and gardening, thus laying the foundation for the college's Vocational School (Wilson, 2006: 60-61).

In 1892, William Goodell Frost begins his service as President of Berea College. For almost thirty years, until 1920, Frost brings a progressive energy to the college and region, recognizing the value of the Appalachian craft tradition, and promoting Berea's unique mission and environment to progressive colleagues at Oberlin College and in New England (Wilson, 2006: 75-80). By 1901, a business block of buildings to "house the Post Office and be a fully modern hotel," is authorized by a committee of Berea College. The block is to stretch sixty-two feet along Prospect Street, 115 feet along Main Street, and 110 feet along Short Street (Boyce, 2006: 40). The Tavern is designed by the New York architectural firm of J. Cleveland Cady \& See (Boyce, 2006: 40). Construction begins on Boone Tavern in 1907 by the Woodwork Department and college-manufactured brick at a cost of $\$ 27,000$. The need for an inn for Berea College guests is expressed by Eleanor Marsh Frost, wife of William Goodell Frost. The need was great; in the legendary summer of 1908, Mrs. Frost reportedly hosts three hundred guests at the President's house.

Howard Taylor arrives in 1909 from Philadelphia, Pennsylvania with his wife to serve as Business Bursar and Manager. Taylor assumes the responsibility for the newly-built hotel, furnishes the rooms with college-made 
cherry furniture which has twenty-five rooms and a tin roof. Mr. and Mrs. Taylor find the building "just as the workmen had left it." Taylor supervises the installation of lights and heating (Boyce, 2006: 6-8).

In September 1909 the first guests register at Boone Tavern at \$2 a day, with "liberal special rates for weekly boarders" (Berea Citizen, June 24, 1909). A tetrastyle portico of four double height Ionic columns on the Prospect Street façade provides a monumental entrance to the hotel. Behind the columnar portico at the ground floor level, a porch with double columns in the Doric order extends across the façade; at the second story level is a smaller porch accessible only from the upper floor interior. The Berea Quarterly, in an article dated October 1909, discusses the origins of naming the new hotel:

The name is well deserved, for Daniel Boone performed his chief exploits in the immediate vicinity. Boonesborough itself is northwest of Berea in the same county, and Station Camp Creek, where Boone and his brother made long stays, is east of us. Boone's Pinnacle is our own forest reserve east of Berea, Scaffold Cane hill is two miles south, and Boones Gap is two miles southwest. The redoubtable hero must have slept many times within a mile or two of the Tavern which bears his name.

The original letterhead for Boone Tavern, in use by 1910, depicts two vignette sketches, one depicting the two story building with the byline, "My Old Kentucky Home," and the other, a Boone Tavern logo with a portrait of Daniel Boone. Due to the instant popularity and success of the hotel, Howard Taylor supervises the addition of a third floor. By 1910, the Tavern's front desk is located opposite the Prospect Street Entrance, the gift shop is located on the east end of the lobby (with windows on Main Street), and a small dining room with a skylight is located on the north side of the Tavern. At the first story level along Main Street, the building that houses Boone Tavern also houses the post office and occupied commercial storefronts. In 1911 the two storefronts on the north side of Boone Tavern are purchased by the College, and the building is extended to accommodate a larger dining room (Boyce, 2006: 40). By 1915 the bathrooms are added to thirty of the best rooms (Boyce: 2006: 40).

Wallace Nutting begins his entrepreneurial small or mid-size furniture-making business in 1917 (Denenberg, 2003: 123) and builds a business with a focus on sensuality, comfort and good value and promotes colonial revival targeting well-off consumers with discretionary income who frequent upscale retailers. After a long career focused on handicrafts, Nutting leaves his business to Berea College supporting the unique approach to education via the Student Craft Industries (Blaszczyk, 2005: 390-393). The Tavern's regional popularity and name recognition grew under the management of Richard T. Hougen, Boone Tavern Hotel manager for 35 years from 1942 to 1976. Hougen developed the first Kentucky program in hotel management (Boyce: 2006: 42). From 19531955 the Tavern was renovated at a cost of $\$ 550,000$. New furnishing "with a home-spun type" modernization of furniture produced by Woodcrafts students and hand-woven fabrics from Fireside Industries were adopted. Boone Tavern housed 203,000 guests in 1972 (Boyce, 2006: 42). In 1992, the Tavern was designated a Historic Hotel of America (Boyce, 2006: 42), and in 2003, the Kentucky Tourism Council named the Tavern winner of the Duncan Hines Excellence in Hospitality Award (Brown, 2008). The 58-room inn continues operations with thirty-nine Berea students working 10-15 hours a week in the dining room and hotel as part of the College Labor Program. Furnished throughout with reproduction Early American pieces made by the College Student Craft Industries Program, large, comfy rocking chairs grace the Tavern porch and windows of the main dining room overlook a number of academic buildings.

More recently, in 2006 the College administrative unit reviewed the current hotel operations, building structure and renovation design for the Boone Tavern Hotel. Since the last upgrade and renovation of heating, electrical, and plumbing systems in 1988 at a cost of $\$ 1.8$ million, rooms have been enlarged and new baths installed in every room. Most recently, the College proposes the complete hotel renovation, which would expand the hotel from 58 rooms to 64 , scheduled in time for Boone Tavern's $100^{\text {th }}$ anniversary at a cost of $\$ 9.6$ million designed to preserve its traditional simplicity and to make it the first "green" or eco-friendly hotel in Kentucky (Jester and Clark, 2007). 


\section{THE RENOVATION CHALLENGE}

As part of the pre-planning for Boone Tavern renovation a College Charrette, held in winter 2006 was convened by the 3north architectural and design firm of Richmond Virginia gathering community participants. The Charrette purpose was to rediscover the qualities of the historic hostelry through a collaborative exercise focused on three questions. The first question addressed the emphasis on service as reflected in the school's motto: Learning, Labor and Service. Service was embedded in the dream of the founders, and the school's Great Commitments "...to emphasize the Christian ethic and motive of service to others" and "to serve the Appalachian region primarily through education but also by other appropriate services." In a broader sense, the preamble to the Great Commitments calls on Berea's students, faculty, and staff to strive toward a world shaped by the power of love, human dignity, kindness, equality, peace, and justice (3north 2007, 25).

Sustainability was the second question addressed by the College Charrette (3north 2007, 25). Sustainability refers to the capacity of a society to meet current needs without degrading the ecological, social, and economic systems on which the society will rely for future needs. In 1999, Berea College established the Sustainability and Environmental Studies (SENS) Program as an important part of the College's commitment to developing a sustainable campus. SENS links the formal curriculum of the classroom to the many opportunities for experiential learning - "learning by doing" -- that come from student, staff, and faculty participation in the continued creation and operation of a sustainable environment at Berea College.

\section{BOONE TAVERN HOTEL AS "VALUE ADDED"}

The Boone Tavern Hotel is an important symbol of Berea College and has been a showplace for tourists, students, faculty, Board of Trustee members, financial supporters and friends, the entire Berea community and the region. In assessing the Boone Tavern Hotel added value to alumni relations, public relations and development, Vice President for Alumni and College Relations William Laramee offers the following observations:

"Boone Tavern is one of the College's greatest assets in terms of public relations, alumni relations and development. The Tavern is an important introduction to our mission and to The College's Great Commitment, and has been pivotal to Berea's fund-raising success. I have often referred to the Tavern as the College's "Basilica" in terms of its impact upon friends and prospective donors" (Finance Committee, May 2006, FIN-15).

Viewed as a gateway to Berea's campus, the Boone Tavern informs and introduces "new friends" of the College who might not have previous contact. The Tavern presents a venue to host College guests and to reinforce mission-related messages of work-related education, the dignity of all labor, simple elegance, and the values of respect, service and appreciation. The Hotel exposes Berea's mission through its students (in the dining room, at the front desk, on student-led tours, etc.) who represent themselves, the Berea College heritage and the Appalachian crafts traditions. The Boone Tavern Hotel also attracts travel writers who publish stories and feature articles in a wide range of media, both mainstream and niche media outlets. These articles, in turn, attract travelers to dine and lodge at the hotel. These articles garner significant amounts of "free advertising" (Finance Committee, May 2006, FIN-15).

The College is able to document, that during the last 30 years, The Boone Tavern Hotel has been featured in more than 64 newspapers and magazine articles, ranging from dining reviews to multi-page, multi-photo feature spreads, achieving 2,170 column inches of positive exposure (Finance Committee, May 2006: FIN-15). The range of the documented publications include diverse media outlets such as national travel magazines like Southern Living and national newspapers such as the Los Angeles Times, Chicago Sun-Times, Christian Science Monitor, and the New York Times, as well as significant regional publications such as Southern Lady and Knoxville New Sentinel. The Washington Times on June 10, 2007 cited the Tavern as a Girlfriend's Getaway (Goldberg Goff, 2007). The latest multi-column newspaper article was published in the Atlanta Journal Constitution on December 11, 2005 and the Chattanooga Times Free Press, November 15, 2007. Recent magazine articles of note for the group travel industry include the January 2006 issue of Travel-South USA, and the March 2006 issue of Southern Living which features two photos - one of Boone Tavern and one of the traditional "chicken flakes in a bird nest" from the historic menu (Finance Committee, May 2006, FIN-15). 
The Finance Committee of the Berea College Board of Trustees (May 2006) attribute the number of bequests received from patrons for whom the Boone Tavern Hotel was a first contact point from 1980 to the present totaled 50 contributions. The total dollars received from bequests and lifetime giving with intended gifts was reported to be over $\$ 8$ million of those who reported they had their first experience with the College came via the Boone Tavern at 52 pledges. The total donations received from outright gifts exceeded $\$ 2$ million from 2,188 persons, and the total number of Boone Tavern Student Fund dollars received from outright gifts over $\$ 400,00 \mathrm{o}$. The total lift-time gifts are forecasted at over $\$ 2$ million. $^{\mathrm{v}}$

\section{STUDENT CRAFT INDUSTRIES AT BEREA COLLEGE}

The Appalachian region has long enjoyed a distinctive artistic tradition developed from a unique combination of social, geographical and cultural circumstances. Appalachian art, we must remember, is work best defined not as an object, but though its excellence in design, respect for materials and honor in the work. In the 1890's, President William Goodell Frost experienced firsthand the design, quality workmanship and sense of pride that existed among the people of the Appalachian region. Dr. Frost's astute recognition enabled him to see beyond the simple fact that these crafted objects would have a tremendous commercial appeal. As an educational visionary, Dr Frost recognized the potential opportunity to effect social change through education and the craft disciplines, allowing Berea College to blur the distinction between manufactured craft items and the opportunity for students to participate in the continuance of a valuable heritage (Boyce, 2006: 68-69). Since 1893, the Berea College curriculum has combined the liberal arts with "practical" studies (from crafts to professional studies like agriculture, technology and nursing).

"Artistic activity that embraces the ideas and visions of different cultures can lead to new and innovative ideas and inventions" (Voluntary Arts Network, 2005).

Berea College has a long-standing tradition as a powerful force in producing handmade crafts, craft education and artisan development. A survey of regional artists yields a number of individuals that owe their start to either the Berea College Student Craft Industries or the Department of Art. An internet search yields another astounding number of well-known, respected and successful musicians, artist/craftsmen, actors, theater personnel and designers who are making their presence known at the national level (who owe their very existence to the SCI program (Glotzbach, 2007) .

In the early 1900's, craft leaders from North Carolina took the weaving skills learned at Berea and started successful programs for Appalachian women in western North Carolina which has now become the internationally renowned Penland School of Craft. The late Rude Osolnik, "Dean of American Wood Turners" and a former Berea College faculty member and head of Student Crafts changed the face of contemporary wood turning with his educational philosophy and innovative design and technique (Glotzbach, 2007, 7). In the 60's and 70's, Osolnik was a leader of the Southern Highland Handicraft Guild and helped found the Kentucky Guild of Artists and Craftsmen having served both as President. He was one of the architects of The Kentucky Guild Train that first started promoting Kentucky crafts. In 1982, he started the ongoing Berea Crafts Festival.

Berea College has been the leader in espousing this philosophical construct and it is most visible in the Student Labor Program, which allows the student to "earn" an education and understand the significance of being part of a living, breathing organization. It is often the experiences in life that are most important, not the outcomes, and many times we are so preoccupied with the outcome that we hesitate to have the experience (Glotzbach, 2006).

"Participating in the arts helps people develop their creativity. Creativity involves imagination and the ability to visualize. 'Seeing' situations as they might be in the future is a valuable tool for solving problems and changing situations" (Voluntary Arts Network, 2005).

Student Craft Industries exemplifies the mission of Berea College as set forth in the College's Great Commitments by providing work opportunities for students, which broaden and strengthen the student-learning and labor experiences as well as provide an understanding of the Appalachian culture (Glotzbach, 2006) 
Student Craft Industries has a nationally recognized line of products produced in five distinct craft disciplines. Included are: Woodcraft - items created using regional woods of Cherry, Oak, and Walnut with natural wood finishes which includes games, kitchen items, furniture, items for office and home, and items of original Shaker design. Broomcraft - producing hand rolled brooms in natural or dyed fibers. Fireside Weaving - producing baby blankets, placements, napkins, coasters and potholders in 100 percent pre-shrunk cotton. The Cottage Couch Throws are a dry cleanable blend of mohair, wool, acrylic, and polyester. Ceramics - The Resident Potter and students of the Ceramic Apprenticeship Program (CAP) produce dishwasher safe stoneware and porcelain objects including mugs, casseroles, ramekins, baking dishes, beverage glasses and pitchers. This discipline has the greatest component of formal instruction. Ironwork - Working with a local blacksmith, students create hand-forged items that include kitchenware, candleholders, hooks, and fire place tools. While these items are distributed by Berea College, they are indirectly a product of Student Craft Industries (Glotzbach, 2007, 11).

The Glotzbach Report (2007) notes, that in spite of the SCI's learning and cultural significance, the contemporary history of SCI has not always lived up to its potential as a business or as an educational program. The SCI product line is "stale" and its business plan too inflexible. Current students often state that their work in craft labor positions is monotonous. They express a desire to be involved in the creative process. A variety of factors have contributed to the decline in SCI sales and the rising costs. In order for SCI to innovate the SCI program it must recognize and respond to these factors. First, today's art/craft buyers are also a different breed. By 2030 one in every five people will be over 60 years old. This 70 million plus population tends to be well-educated, wealthy and particularly interested in both quality and good design. The so-called "Boomer Generation" is hardworking and expansive in their recreational and buying interests. They appreciate tradition and its connection to modernity. The "Generation X'ers" are tech savvy, have disposable income and enjoy having nicely made furnishings in their homes. As America has moved deeper into virtual and indirect experiences, it seeks out authentic "root" experiences. An over-commercialized, low-touch, high technology existence often leaves X'ers empty and they are drawn toward the tradition, authenticity and humanity of handcraft. Craft offers these experiences to the maker, the viewer and the collector (Glotzbach 2007, 8).

Second, in today's marketplace craft has become part of the mainstream, no longer sold at roadside stands and open-air markets. Craft is available at major trade shows, on the pages of catalogs and dotcoms, in fine art galleries throughout the world and is avidly collected (Glotzbach 2007, 8).

Third, contemporary society's educated consumers of craft easily connect to the process and its maker. They desire a craft object and a connection to the traditional values that it represents. The craft object is not only valuable to them for what it is (functionally or aesthetically), but for the story that it tells. Those who appreciate and consume craft also want to share a common bond in the creative experience. Artisans and communities who have discovered this concept are now at the forefront of educating an already astute public, generating successful new artisans and fulfilling the needs of a consumer who has tired of the separation of maker and buyer. It is here that Berea College has its greatest potential (Glotzbach 2007, 8).

"Understanding and acknowledging the incredible economic impact of the (non-profit) arts, we must always remember the fundamental value of the arts. They foster beauty, creativity, originality, and vitality. The arts inspire us, sooth us, provoke us, involve us, and connect us...but they also create jobs and contribute to the economy." (Robert L. Lynch, President and CEO of Americans for the Arts, 2007).

This concept coincides with the fourth factor. This factor presents the nature of cultural heritage tourism, professional development for artists, student craft education, and affords Berea College the opportunity to develop new internal and external partnerships in its crafts program. Glotzbach (2006) believes that through these new avenues of tradition and modernity that Berea College can redefine its Student Craft Industries, correctly focusing on the education and engagement of the student in the creative process. Thus, the intent becomes one of investment in educational opportunities as well as the expense of the crafts "business." It is not an irreconcilable notion to continue the production of craft works and increase student learning opportunities while reducing some of the current problems of student labor costs, high labor turn-over rates, material costs and over-staffing. 
The fifth factor is awareness that almost 60 percent of all craft sales nationwide are related to tourism people traveling to purchase crafts. Surveys indicate that the retail sector is the largest crafts distribution method (52.9 percent), followed by wholesaling within the United States (27 percent) and consignment to galleries (11.2 percent). Only 0.47 percent of crafts were distributed outside the United States (Woronowicz, 2004).

Scott Krugman $(2002,112)$ finds that "people are looking to give meaningful gifts of lasting value. [That trend] would put craft dealers in a more competitive position," Krugman says. A recent retail survey commissioned by CERF, Craft Emergency Relief Fund reports that retail sales are without a doubt the leading sales method for artists and galleries alike.

Glotzbach (2007) identified four learning goals for integrating the Berea College culture with SCI including: 1) Creating student-centered learning experiences that include student design, problem solving manufacturing teams, and business education/experience, 2) Developing a College-wide program of creativity training, design \& innovation to enhance creative capacities of the entire student body, 3) Encouraging cooperation and collaboration between Student Craft Industries and various college departments such as Art, Technology, and Business and 4) Providing methods for the design of new products and development of new markets, including work with architects, interior designers, and industry

Glotzbach $(2007,14)$ quotes Powell (1974) remarks:

"The arts, including the crafts, grow as a response to a particular culture, place and time. They help form the culture. Is it not retaining more of the real spirit of Appalachian Crafts to create an atmosphere of craft development within the region in the direction of a new relevance to our own people and times? Isn't this the first responsibility of regional Appalachian development in the crafts? This task cannot be done by copying the past, although it grows from the past. It cannot be done by fitting today's craftsmen into a traditional mold from which there is no freedom to move and grow toward a regional expression. Nothing is deadlier to creative expression than stagnation.

"Appalachian craftsmen must be given every possible exposure to good design, to diversified technique and approach. Once these become familiar tools for expression, the craftsmen of Appalachia are freed to develop their own styles. Only through the bringing of the best teachers and craftsmen from many sources, both from within and without Appalachia, can the region become capable of producing its own significant contemporary style and its own designers. These changes will not occur overnight; nor will they occur without great effort exerted."

\section{GLOTZBACH RECOMMENDS SPECIFIC CONNECTIONS TO BOONE TAVERN}

Glotzbach (2007, 19-20) cites one specific recommendation to involve Student Craft Industries in renovations at historic Boone Tavern Hotel, particularly in relation to supplying Wallace Nutting furniture items to the rooms or the development of new furniture items. The SCI, the Art Department and the Department of Industrial Technology should work with the designers and architects in the development of new items for the planned renovations at Boone Tavern. Not only will this begin to bring about a unity among these groups, but it insures the generation of multiple ideas and viewpoints. This collaboration also allows the design and development process to begin in a systematic way with all potential players at the table. While it is not yet possible to determine the direction of the intended renovation, conversations involving all the intended participants should begin as soon as is feasible. If new items will be produced by staff and students, these items should be considered for inclusion in the catalog as limited edition pieces. The items themselves would, of course, also be on display in each room. Student designers should be given credit for their individual designs as well as recognition to the students in the production phase.

\section{TEC 140 PRODUCTION TECHNOLOGIES IN WOODS COURSE DESCRIPTION:}

The TEC 140 Production Technologies in Woods course provides an opportunity to "trial" several of the Glotzbach recommendation. The course description states: "A study of selected production processes through considerations of wood and wood materials. The course encompasses material properties, ergonomic design, prototyping, production design and primary and secondary processing. Instruction will include material selection, 
design, problem solving, fabrication, and finishing. Summary of course content includes wood and wood materials, sawing lumber, drying lumber, wood properties, and processing wood; Layout and conservation of materials with a focus on lumber computations and calculations, project planning, working drawings, and bill of materials; Design of wood properties, furniture styles, function and design; Wood processes with application to separating, forming, combining, assembling, and finishing; Tools and machinery includes hand tools, machine tools, CNC machines, maintenance; Furniture Construction and examples of joinery and fastening; and Finishing with examples of types of finishing, applications of finished and Production" (Mahoney, Spring Term 2008).

\section{COURSE GOALS AND OBJECTIVES:}

Professor Mahoney developed the TEC 140 course goals and objectives. The five goals were 1) to develop understandings of the area of production technology, 2) to gain experiences in production technology, 3) to be knowledgeable of and able to apply basic principles for problem solving as related to design and production engineering, 4) to know basic principles of material and equipment usage and 5) to develop understandings and skill in communications. The TEC 140 objectives: As a result of this course, each student will develop knowledge and gain experience in; design, planning, application of materials \& processes and construction, as it relates to production technology. This will be demonstrated through the completion of a common and independent project(s) (Mahoney, Spring Term 2008).

Two Berea College professors developed a modular course of action within the TEC140 class. The guiding principle for the module was the demonstration in-class of "real-world" entrepreneurial concept techniques. Most students enter the class with a mainstream understanding of education process. Problem solving, individual understating and original thinking are not emphasized in most high schools or curriculums. In order for design students to succeed they must emphasize and promote innovative and creative thinking. This is a valuable skill that they will carry with them for the remainder of their professional careers. Learning activities included the use of "stacked rank forms" to permit TEC 140 class member to provide written ranking and comments to other teams in "practice" rehearsals and in the final judges' presentation. All formal TEC 140 presentations were video-taped. Presentations were limited in 5 to 10 minutes and coaching sessions were provided to teams in the classroom. Members of the Boone Tavern Review Committee would serve as judges. Learning outcomes for the Boone Tavern case study as cited in Exhibit 1

\section{IDENTIFYING LAMP DESIGN CHALLENGES FOR THE BOONE TAVERN HOTEL}

Ferreira $(2001,112)$ describes the value of lamps as "artificial lighting affect(ing) the lives of billions of people around the world each day". Ferreira contends that ". . lamp manufacturers continue to introduce new products and technology at a pace which might surprise even Messrs. Edison and Swan." Here he was referring to Thomas Alva Edison and Joseph Wilson Swan, who established the Edison and Swan United Electrical Lighting Company, 120 years ago, inventing and producing some of the world's first carbon-filament vacuum incandescent lamps.

Glotzbach identified the starting point for the lamp design problem and conducted a short presentation to the class introducing the product category and requesting student teams within the design studio to identify user problems that can be associated with hotel floor, table and desk lamps. Students were asked to investigate the Boone Tavern Hotel history, renovation plans and lamp use through user observations, secondary research, and one-on-one user inquiries.

To help each TEC 140 team to see how a design studio executes the process of designing a better product, the professors required students to view an ABC Nightline DVD of the design process at IDEO, a well known Palo Alto, California-based design consultancy firm works with clients as diverse as eBay, Prada, Pepsi-Cola, Samsung and Procter \& Gamble, IDEO has developed a string of iconic products, such as the Apple mouse, the Palm V and the Oral-B grip toothbrush for children outside of class time, placing the DVD in the library for student viewing.

The thrust of the documentary was simple. ABC Nightline took an everyday product, something old and familiar, the shopping cart and challenged IDEO to completely redesign the shopping cart in just five days. IDEO's 
model includes part anthropology (with IDEO's trained anthropologists), part site exploration (with IDEO's trained architects), part documentary filmmaking (with IDEO's trained media artists); their approach is to seek the qualitative essence of the community from the perspective of the community (Kelly 2000).

IDEO's unique brand of brainstorming is called "Deep Dive," a sort of total immersion into the design problem is illustrated on the DVD. The "Deep Dive" has become the firm's signature secret weapon for innovation. A "Deep Dive" is designed around the assumptions of Joseph Surowiecki (2005) and Thomas Friedman (1999), both making the point that, "none of us is smarter than all of us." The video illustrates key design principles which may or may not have been familiar to the TEC 140 students. These principles included: 1) valuing different and diverse perspectives within the design team; 2) focusing the design team on key issues important to the client (such as safety and security because 22,000 child injuries a year are caused by shopping carts travelling at a speed of $35 \mathrm{mph}$ in a gusting wind in a parking lot and carts are frequently stolen to serve as mobile storage or barbecues); 3) urging the designers to get out of the studio and talk to people valuing people perspectives that hold the keys to innovation (examples include people who use, make and repair carts); 4) reassembling the team membership at the end of the day to share the keys observations with each other (existing shopping carts were hard to steer, expensive to maintain, easy to steal, difficult to load and unload, and unhygienic and dangerous to children); and 5) collaborate and glean insights into a product feature and benefits (reporting on observations from shoppers, store owners, and cart manufacturers) in a brainstorming session known as a "deep dive" - a total emersion in the design problem.

An IDEO deep dive is run with five entrepreneurial conceptual rules: 1) stay focused on the problems at hand generating a quantity of ideas, 2) encourage crazy and wild ideas through the use of visual drawings, 3) defer judgment, 4) execute one conversation at a time, and 5) build, jump, leapfrog and piggyback on the ideas of others. Eventually, under the direction IDEO David Kelley, and Peter Skillman, the ABC "deep dive" resulted in the formation of four separate groups to focus on four different design problems: shopping, safety, checkout, and finding what you are looking for in the store.

TEC 140 students were trained to replicate the IDEO rules and techniques. Students were encouraged to make active use of a sketchbook to record visually all information relevant to their current design experience. One group designed a "flip-design" book to interconnect various lamp shades, a variety of lamp stems and diverse lamp bases. The flip action allows them to visual diverse perspectives. Students were encouraged to enter five types of information in their visual diaries: 1) information, images, and ideas related to the lamp design; 2) that problem design description; 3) design insights obtained from interviews, observations and secondary research, 4) design problems they noted both in their work and in the review of other teams' work by sketches, images, and descriptive words; and 5) thought or images that are important to the designer for almost any reason that can serve their learning needs above this design assignment.

Lamp design elements poured out of the TEC 140 sessions and were posted on the walls in a series of $3 \times 5$ cards and Post-it notes. Teams were encouraged to vote on their favorite idea and design elements. "Enlightened trial and error succeeds over the planning of the one design genius" was a statement overheard by one participant which the team member witnessed on the video. The TEC 140 class replicated the four design studios but competed directly with one another to solve all the lamp problems.

The DVD illustrated the extensive in-house modeling and rapid prototyping facilities with each group building a working prototype to express and illustrate their ideas and address a certain problem. The TEC 140 class had one week to prepare "drawings" of their product features and benefits and present them to the Tim Glotzbach serving as a representative to the Boone Tavern Hotel decision makers. Glotzbach articulated key criteria that he anticipated the review panel would use in selecting which if any designs would go forward for presentations to the manufacturing groups and the final furniture selection committee. This criteria included: The Story of the Hand, Connections to Home, Essence of Hospitality, Danish Design, Shaker Lessons in Simplicity, Colonial Furniture, Early American Furniture, Wallace-Nutting Furniture, Greek Revival, Berea Craft History, Discovery, Understated Elegance, Craftsmanship, Visual Experience, Tactile Experience, Return to a Safe Place, Appalachian Mountains, College Square, Tulip Style Bed, Acorn Style Bed, Ridgeway Style Bed, Boone Tavern, Education and Natural Environment. 
TEC 140 teams were instructed to include specific criteria in the wooden prototypes and product presentations after having each spent 20 minutes with Tim Glotzbach reviewing in detail each teams drawing. Tim Glotzbach also served as Director of Student Craft Industries and provided specific constraints associated with the production and manufacturing requirements.

These lamp drawing concepts were reviewed and the best ideas went forward into a second round of prototypes. In the TEC 140 case, these lamp prototypes now included wood selection and veneers, lamp shades, grommets, base design, switches, electrical wirings, environmental compact fluorescent light bulbs and one prototype example of a desk, a table or a floor lamp. Student teams models were from 3-D designs to wood mock-up prototypes. The TEC 140 professor opened the machine lab over a long week to facilitate access and experimentation with the mock-up prototypes.

The criteria for the judges in the final product prototypes and oral presentations are displayed in Exhibit 2. This review included a bigger and broader judging panel consisting of the Bonne Tavern Hotel manager, the Vice President of Finance for the College and the director of the Student Craft Industries. Student teams were guided by another professor in how to present new product concepts in 10 minutes blending the best speaker in the team, application of storytelling and the effective use of the new product concepts question and answer time.

While it took three days for IDEO to assemble the final shopping cart design, the TEC 140 class incorporated the best elements from the free-wheeling, multi-disciplinary innovative approach in two weeks. From idea to product prototype concepts with new diverse teams with wide skills set in wood design in 6weeks. By going behind the scenes at IDEO the ABC Nightline documentary revealed an innovation blueprint for Appalachian industries based upon the entrepreneurial concepts that chaos can be constructive, the boss does not always have all the answers, and that teamwork, not hierarchy, is all-important.

\section{JUDGES COMMENTS:}

Oral and written comments were provided to each team. As examples, short comments are provided below:

Team 1-- Projected the cost of the lamp to be $\$ 25$ - however the labor factor was not included. Lamp stability was a concern. The overall design was appreciated with some changes to highlight the lines when the light is turned on.

Team 2-Effective deep thought was given to the operational side of the hotel regarding how easy it would be for the housekeeping staff to clean and dust the lamp. The projected lamp cost was forecasted at $\$ 130$ not including the labor. They did a quality job of researching the cost breakdown of the lamp. Shorter lamps make for poorer vision. There was not enough light for reading, especially for Boone Tavern senior guests. The barbell look is not as attractive. The fluting was a nice touch.

Team 3-- The team was dressed professionally. The team went to Boone Tavern to research the style of furniture and lamps currently in use and spent several hours with hotel staff members. They projected the cost to be $\$ 120$ which is within the budget range. The team included a handout piece with the lamp and cost breakdown - a nice touch. Their style was influenced by the Nutting design.

Team 4-Linked their design to the Tulip Design with a projected cost $\$ 42$ plus labor. They did not know what the labor cost would be. They should know this as part of the overall process that will help determine if the lamp fits into the allocated budget for the lamps within the Boone Tavern budget. They knew the height of each style of lamp that would be used for floor, desk, and table lamps. They were creative in their presentation by showing a photo of the lamp imposed on the current room furniture and it gave a contrast to the actual lamp in use and their prototype. They needed a longer shade to cover the lamp hardware.

Team 5-- Made good very effective use of Boone tavern architectural drawings. Good job on lamp effect in the room. Projected cost \$39. Three hours time to produce. 
The judges continued the design review and conversation. One judge stated "I would need to see the lamps again side by side to fine tune my notes with the actual lamps; as I was only able to look at the lamps up close for about 8 minutes and would like more time. What I can remember at this point is that team 4 had thought about each type of lamp that would be used depending on the size of the room. This would make the production process more consistent and the overall lamp package would fit well together consistently and in alignment other design elements in the rooms."

Another judge stated, '...All the lamps were fairly consistent with the current furniture look and feel. I would have liked to have seen at least one new contemporary style lamp just to see how it would fit. We want to honor the Boone Tavern and Hotel history but at the same time present a new understated elegant look. Tricky to make this work but it would be fun to see one of the teams take a risk and try."

A third judge commented on ..."Hotel guests prefer good lighting for reading in a chair, at the work desk or in bed for reading but also need some options for softer lighting as well in case one guest is trying to sleep while another is reading or working on their computer."

\section{STUDENT TEAM REACTIONS TO THE ENTREPRENEURIAL CONCEPTS}

Students completed "stacked ranking" and self reflective feedback card on two occasions throughout the course and at the end of the judging to record their learning observations. Comments included: "Under time constraints we can get things done." "I learned that every person has their key part in the design group." "From my individual preparation I saw that some groups had some good or better organization and had put some thought to their planning and assigning tasks." "I gained an appreciation of wooden lamps and wood working techniques." "I was amazed at my own contributions of time and thought, and my help furthered the success of my group." "From large class discussion I learned about brainstorming and the iterative process of doing it over and over and over, not just once." "I was surprised by the amount of time and effort that goes into something that appears simple." "I learned that time management is a must." "I have gained insight and appreciation regarding the plan for the renovations of Boone Tavern and certainly the inn as an art form." "The most successful part of this experience is an understanding how to operate new wood machinery and to see how design links to production." "Designing is harder than it looks." "I developed hunches of creativity and how to develop group thoughts and a quantity of ideas." "From this experience I learned the long process of creativity - full of trial and error." "My ability to be creative has increased greatly!" "I can go to Gary Mahoney for an opportunity to practice and gain new skills." "The people who are in my extended network to help me practice these skills are the TA's and Dr. Mahoney, Dr. Hackbert and Tim Glotzbach." "I can go to open labs on my own for an opportunity to practice and gain skills." "I want to practice the teamwork aspect more thoroughly in the future to strengthen my skill set." "I was proud that we finished it."

\section{CONCLUSION}

Berea College has a reputation for innovative thinking and innovative teaching and learning. This program illustrates how to apply entrepreneurial concepts around idea generation, opportunity recognition, and rapid prototyping and can be applied for advancing product design. It demonstrates one approach for utilizing student designers as a basis for additional learning opportunities. As Berea College stands at the advent of its next 150 years, it is important to realize that the College now educates a very different student in many respects, but still one who comes filled with the traditions of time and place and with curiosity about these roots. The need to extend and preserve regional crafts and their skills fall within the scope of Berea's Appalachian commitment.

"Every Course in the college curriculum seeks to enable our students to think at once in terms of the world and the mountains." (William J. Hutchins, President of Berea College, 1920-1938). 


\section{Exhibit 1 - Creativity, Invention, and Innovation Modular Elements:}

1. Strengthen the TEC 140 individual student's and studio teams' creative strengths and abilities. a. Illustrate the idea generation process, designer sketching process, and prototyping design process through the Boone Tavern "bed design case study."

b. Include the time frame for each stage and major deliverables (or sample illustrations) for each stage, identify source of information that informed the design team as to specific design elements to include in the process.

2. Discussion of creativity techniques through the illustration of the Deep Dive DVD and conducting a class discussion highlighting: 1) time schedule for the design process, 2) diversity of the design team, 3) various roles played by studio design members, 4) methods executed to investigate underlying needs and latent buyer desires, 5) "Deep Dive" brainstorming techniques to stay focus, be playful, produce a big quantity of ideas by numbering ideas, build and jumping off of team members ideas, use of white space and visuals, warm-up group activities, being visual during the creative process.

3. Discussion and presentation by the Boone Tavern interior design team, architectures and interior designers as to the considerations desired by to the Boone Tavern decision makers.

4. Practice-based skill sets development via focused training practicing IDEO techniques applied to the Boon Tavern case study including "improv techniques" for the studio teams, training and execution of at least three "Post-It notes" observations and investigative techniques, in-class brain storm and of design elements, in the classroom.

5. Individual TEC 140 or studio design teams create, design and show an early stage idea new wood product drawing to the Boone Tavern buyer based upon: 1) the "quantity" of individual or studio team drawings and 2) findings / considerations of primary field research and summary of studio investigative secondary techniques that were considered significant in the idea generation stage of the wood product design process.

6. Develop a "1 1 st stage prototype" constructed of a "non-wood" material to speed rapid prototyping (form cord) and present it to the buyer.

7. Develop a " $2^{\text {nd" }}$ stage prototype of constructed in the individual or studio wood of choice and present it to the buyer. Include a formal presentation of:

a. Summarize the key design elements emerging from the investigative techniques.

b. Breakdown the specifics of each item(s) in term of quantity of raw materials, out-sourced components and changes required in the manufacturing process of Student Crafts Industries.

c. Breakdown and summarize the cost to manufacture the item(s) and summarize the quantity and cost for the total quantity of items for the buyer.

\section{Exhibit 2 - Criteria for Boone Tavern Hotel Judges Final Products Prototypes and Oral Presentations:}

1. Was there an obvious theme presented that relates to Boone Tavern Hotel? or Did the team create an entirely new theme that inspired the judges?

2. Did the team begin to move beyond obvious connections and create connections that inspire the judges to look further?

3. Does the design answer the basic needs requested including price?

4. Did this team research reality, design abstractly and execute concretely?

5. Did the team try to convince the judges that the Boone Tavern Hotel judging panel needs should be changed or significantly altered to fit their design?

6. Does this team have the spirit to continue the design process through to completion or it "over" for them?

7. Does the design fit the overall concept of Boone Tavern Hotel renovation?

8. Does the team understand the history and traditions of Student Craft industries and the plans for the future?

9. Is the product in keeping with the "handmade" tradition of Berea College Student Crafts Industries?

10. Does the design have an educational component- i.e. will the students in Berea College Student Crafts be challenged to learn new concepts pertaining to history, design, craftsmanship or technique?

11. Can this be prototyped and actually produced here within the Berea College Student Crafts? 


\section{REFERENCES}

1. $\quad 3 n o r t h, 2007$. Boone Tavern at Berea College Intangibles Qualities. Richmond, Virginia.

2. $\quad$ Berea Citizen, June 24, 1909; quoted in Richmond Daily Register, December 1, 1967.

3. Blaszczyk, Regina Lee, 2005. Wallace Nutting and the Invention of Old America, The Journal of Design History, 18 (4): 390-393.

4. Boyce, Robert, 2006. Building A College: An Architectural History of Berea College, Berea, KY: Berea College Printing Services.

5. $\quad$ Brown, Katherine, February 2008. "The Tavern and the Green,” The Lane Report, Vol. 23 (2): 46.

6. Cooke, P., 1996. "Building a Twenty First Century Regional Economy in Emilia Romagna." European Planning Studies 4(1): 53-62.

7. Cooke, P., 1998. "Introduction: Origins of the Concept". in H.J. Brazyk, P. Cooke and M. Heidenreich (eds.) Regional Innovation Systems: The Role of Governance in a Globalized World. London: UCL Press, 2-27

8. Coy, Peter, August 28, 2000, "The Creative Economy," Business Week, (Special Double Issue: The $21^{\text {st }}$ Century Corporation), Business Week Online: 1-5, Accessed at www.businessweek.com/2000/00_35/b3696002.htm.

9. DCMS (2001), written at London, UK, Creative Industries Mapping Document 2001 (2 ed.), Department of Culture, Media and Sport, http://www.culture.gov.uk/Reference_library/Publications/archive_2001/ci_mapping_doc_2001.htm, Retrieved on 04-21-2008.

10. Denenberg, Thomas Andrew, 2003. Wallace Nutting and the Invention of Old America. New Haven, CT: Yale University Press.

11. Diez, M. A., 2002. "Evaluating New Regional Policies: Reviewing Theory and Practice". Evaluation. London: Sage Publications.

12. $\quad$ Ferreira, Ted, October 2001. “The Latest In Lamps,” Lighting Dimensions.

13. Finance Committee, Berea College Board of Trustees, May 2006. Plan to Enhance Boone Tavern Hotel and Restaurant, Berea, KY: Berea College Board of Trustees.

14. Florida, Richard, 2002. The Rise of the Creative Class. And How It's Transforming Work, Leisure and Everyday Life. New York: Basic Books.

15. Florida, Richard, 2008. Who's Your City: How the Creative Economy is Making Where You Live the Most Important Decision on Your Life. New York: Basic Books.

16. Friedman, Thomas, 1999. Lexus and the Olive Tree. New York: Farrar, Strauss and Giroux.

17. Glotzbach, Tim, February 24, 2007. Administrative Committee Review and the Glotzbach Report on Student Craft Industries. Berea, KY: Berea College Student Crafts.

18. Goldberg Goff, Karen. June 10, 2007. "Girlfriends Getaways," The Washington Time, D01.

19. Hall, Kim, 2008. 10 Great Towns for Working Artists. Art Calendar - the business magazine for visual artists. Assessed at http://www.artcalendar.com/article.asp?ID=70.

20. HandMade 2003a. The Craft Heritage Trails of Western North Carolina,_HandMade in America, Asheville NC.

21. HandMade 2003b. Farms, Gardens and Countryside Trails of Western North Carolina, HandMade in America, Asheville NC.

22. Howkins, John, 2001. The Creative Economy: How People Make Money from Idea, New York: Allen Lane, The Penguin Press.

23. Hustede, Ron, 2007. "What's Culture Got to Do With it? Strategies for Strengthening an Entrepreneurial Culture, in Entrepreneurship and the Local Economic Development, Norman Walzer editor, Lexington KY: Lexington Books,

24. Ivankovich, Michael, 2004. Collector's Guide to Wallace Nutting Furniture (Paducah, K Y: Collector Books: 57.

25. Jester, Art and Ashlee Clark, December 21, 2007 Friday. "Boone Tavern to get a green makeover," Lexington Herald-Leader, Kentucky,

26. Kelly, Tom 2000. The Art of Innovation. Lessons in Creativity from IDEO America's Leading Design Firm. New York; Doubleday. 
27. Kolbasuk McGee, Marianne, May 26, 2006. "New IBM Program to Woo Appalachian Students into Tech Jobs." Information Week, Accessed online April 21, 2008, http://www.informationweek.com/news/management/outsourcing/showArticle.jhtml;jsessionid=RT4NFDI YIYFIYQSNDLRSKHSCJUNN2JVN?articleID=188500241\&_requestid=181227

28. Kotlin, Joel, 2000. New Geography: How the Digital Revolution Is Reshaping the American Landscape, New York: Random House.

29. Kungman, Scott, 2002. Surfing the Wake: Can Craft Sales Survive Tough Times, Kara Laughlin, Crafts Report, January.

30. Lynch, Robert L. 2007. Arts \& Economic Prosperity III: The Economic Impact of Nonprofit Arts and Culture Organizations and Their Audiences in the City of Savannah, Savannah Dept. of Cultural Affairs's web site at www.savannahga.gov/arts accessed at

http://www.savannahga.gov/cityweb/culturalaffairsweb.nsf/608e11690577454885256af400535d5b/4ef48f3 82cdc514e852572f20072914b?OpenDocument as retrieved on Apr 13, 2008 14:57:32 GMT.

31. Mahoney, Gary, Spring Term 2008. TEC 140 Production Technology in Woods Course Description. Berea KY: Department of Technology and Industrial Arts. Accessed via email April 20, 2008.

32. Marshall, A. 1949. The Principles of Economics, 9th ed, London: Macmillan.

33. Park, Sharon C. 1993. "Sustainable Design and Historic Preservation," CRM, No 2, 13-16, available at http://crm.cr.nps.gov/archive/21-2/21-2-4.pdf

34. Powell, Naoma, 1974. Appalachia: Crafts, Skills, and Poverty, Quicksand Craft Center, Vest, Kentucky.

35. Quote DB, 2008. Welcome to Famous Quotes at Quote DB - Interactive Database of Famous Quotations, http://www.quotedb.com/ accessed April 21, 2008.

36. Regional Technology Strategies, Inc. 2003. Clusters of Creativity: Innovation and Growth in Montana The Creative Enterprise Cluster A Report to the Montana Governor's Office of Economic Opportunity Regional Technology Strategies, Inc. Carrboro, North Carolina.

37. Regional Technology Strategies, Inc. April 2007. Creativity in the Natural State: Growing Arkansas' Creative Economy, Volume 1, Regional Technologies Strategies, Inc., Carrboro, North Carolina.

38. Surowiecki, James, 2005. Wisdom of Crowds, Random House, New York.

39. Wilson, Shannon, 2006. Berea College: An Illustrated History. Lexington, Kentucky: The University Press of Kentucky

40. Weeks, Kay D. and Anne E. Grimmer, 1995.Guidelines for Preserving, Rehabilitating, Restoring \& Reconstructing Historic Buildings U.S. Department of the Interior National Park Service Cultural Resource Stewardship and Partnerships Heritage Preservation Services, Washington, D.C. Accessed April 20,2008 at http://www.nps.gov/history/hps/tps/standguide/

41. Woronowicz, Stephanie, A. March 2004.''I want this'- The price of authenticity," The American Observer, Vol. 9 No. 5.

42. Wu, Weiping, February 2005. Dynamic cities and Creative Clusters, World Bank Policy Research Working Paper 3509, http://wwwwds.worldbank.org/external/default/WDSContentServer/IW3P/IB/2005/03/03/000012009_2005030315233 0/Rendered/INDEX/WPS3509.txt, Accessed online April 20, 2008.

\section{NOTES}

${ }^{\mathrm{i}}$ John Howkins has documented the global impact in The Creative Economy: How People Make Money from Idea, New York: Allen Lane, The Penguin Press, 2001. The New England Council in June 2001 produced a report, The Creativity Economy Initiative, limiting the definition of the creative economy to artistic and cultural fields. More recently, the concept of creative clustering is introduced by Richard Florida, Who's Your City, New York: Perseus Books Group, Basic Books, 2008. Florida suggests that the real source of economic growth comes from clustering and concentrating talented and productive people. New ideas are taken for granted and the productivity increases when talent is located close to one another in cities and regions. The clustering forces makes each community member more productive, which in turn makes the places inhabited more productive, generating great increases in output and wealth.

ii Some may say that the creative class is essentially just a group of highly educated people. While education and creative occupations are correlated Florida suggests that they play very different roles in economic growth. Research uncovered another way in which occupations affect regional growth. Certain kinds of jobs mean more to a regional economy than others. While 
many people assume that wealth generates and sustain the arts and entertainment occupations, what appears to be more profound is Alfred Marshall's concept of "agglomeration," introduced in 1949. New regional theory suggests new theoretical approaches to development that emphasize learning in creating local areas that are able to stand up for themselves and adapt to the new competitive conditions imposed by globalization. From this perspective, sustainability in rural development lies in viewing rural development through networks of inter-firm cooperation and innovativeness. This is achieved through creation of knowledge and building learning capacity (Dies, 2002). Regional policies that emphasize sustainable regional development are aimed at innovation in companies, in company clusters, and in institutions and in organizations that support innovation.

iii Creative enterprises, like other industries, tend to cluster more heavily in some places than others, either because of a special location advantage, historical roots, or just a pure chance event. Creativity flourishes where creative people socialize, develop relationships, and form networks. An environment where ideas can be easily exchanged inspires creativity. An economy operates as a system and includes all of the other enterprises necessary to do business: those that sell, supply, reproduce, or otherwise contribute to the same products (Regional Technology Strategies, Inc. April 2007).

iv An alternative perspective to the creative enterprise cluster or tiers, are enterprises wherein innovation lies at the core of its mission and where innovation represents the firm's strongest competitive advantage. Technology and the creative arts are increasingly intertwined through computer based design, drafting, and graphic arts programs; filming, digital photography, art, and music; optics and imaging; and web-based marketing as examples. Firms with products that incorporate art into products and creative content into services also use a variety of industrial and information technologies to meet market demand. Proximity to the developers and producers of the technologies is perhaps less important than it is in embryonic or mature clusters, but nonetheless proximity is an advantage. Access to the experts among companies in the supply chains who keep abreast of new market technologies suffices and is an adequate substitute for most of the enterprises and entrepreneurs in a cluster. Despite the use of technology in some parts of the cluster, however, businesses in a cluster are not typically associated with highly advanced technology.

$\checkmark$ Most of these gifts came from anonymous people who most likely ate at the Boone Tavern Hotel but may have also simply toured the building or stayed in a room. 